\title{
Virtual space utilization in the Digital SMEs Kampongs: Implementation of Smart City and Region
}

\author{
Rini Rachmawati*, Sinthia Alfianita Hapsari, \\ Anggun Mutiara Cita
}

Universitas Gadjah Mada, Indonesia

\begin{abstract}
Efforts to integrate the use of ICT in various aspects of urban and regional development is the embodiment of the implementation of the smart city and region. One of the efforts is by developing a smart economy and smart business through Digital Small and Medium Enterprises (SMEs) Kampongs. This research is aimed at; 1) identifying the existence of Digital SMEs Kampongs, 2) identifying the Digital SMEs Kampongs' activities, 3) analysing the implications of the use of virtual space on the Digital SMEs Kampongs' activities. The primary data have been conducted through observation and in-depth interview. The results show that the existence of the Digital SMEs Kampongs can increase the use of virtual space, make the smart economy and smart business opportunities, improve the ability of community in running businesses and develop advanced SMEs. It has contributed to the achievement of smart city and region.
\end{abstract}

Key Words: Virtual Space, Smart City and Region, Digital SMEs Kampongs.

Article Info: Received: October 12, 2017; Revised:January 9, 2018; Accepted: March 19, 2018; Online: May 25, 2018.

\section{Background}

Discussions on virtual space have been done by many urban experts associated with the strengthening of the role of information and communication technology (ICT) in development. Among them is the strengthening of the role of virtual space as activity space, economic space, movement space and interaction space (Rachmawati and Rijanta, 2012; Rachmawati, 2014; Rachmawati et al., 2015). Today virtual space is not only used as a means of communication

\footnotetext{
* Corresponding address

Address: Department of Development Geography, Faculty of Geography, Universitas Gadjah Mada, Indonesia.

Phone: +628.121.598.066 | Email: rinirachma@ugm.ac.id
} 
through social media but also as a space for running economic activities. Some terms that are related to ICT-based economic activities and are often used are ecommerce and e-shopping.

The terminology of space in human geography has long been in contact with the virtual space as a part of relative space and absolute or contextual space as well (Goodall, 1987). However, in the context of Geographical Science the structure of new space concept due to the strengthening of virtual space needs to be more stressed out (Rachmawati, 2011; Rachmawati and Rijanta, 2012; Rachmawati, 2014) and exemplified in its implementation, particularly the one related to human lives in various activities of a human. One of them is economic activity. Space is needed in it. Up until now, space has only been understood as a physical one. In the era of information and communication technology, the existence of virtual space is becoming more evident (Rachmawati, 2011; Rachmawati, 2014).

Efforts to integrate the use of ICT in various aspects of urban development constitute the realisation of implementing the concept of Smart City. It has become a new trend of urbanisation and urban development (Rachmawati, 2016). Smart City can be made up of several components such as smart governance, smart environment, smart people, smart living, smart infrastructure, smart economy and so on. The main point of it is how each component is applied more smartly with the support of ICT to make it much easier to work with.The use of information and communication technology in the economic field, popularly called the smart economy and smart business, has led to ICTbased economic activities that are more sophisticated. The use of ICT contributes to helping a city reach sustainable economic growth in the long run as well as the quality of better life for the urban stakeholders (Anthopoulos and Tougountzoglou, 2012 in Bifulco et al., 2016).

In relation to ICT-based economic activities, it is PT Telkom Indonesia that has launched an improved Digital SMEs Kampongs. This phenomenon has been a new trend that needs to be further studied. In the past, SMEs was regarded as the one of not being capital intensive, supported with simple equipment, promoted in limited coverage and having the limited workforce. However, it is undoubtedly possible that e-commerce will be able to solve those limitations. It is also necessary to study further how much the SMEs agents have made use of ICT in running their businesses. In a broader context, it is intriguing to explore further how far the activities of digital SMEs contribute to the development of kampong and or its neighbouring areas. Besides, it is also essential to study how far the existence of Digital SMEs Kampongs can support efforts in establishing a smart city. In this case, which component of a smart city is the most prominent. Furthermore, this study is aimed at 1) identifying the existence of Digital SMEs Kampongs in Indonesia as one of the realizations of smart economy, 2) identifying the activities of Digital SMEs Kampongs based on the case examples of Digital SMEs Kampongs, 3) analysing the implications of the use of virtual space for the activities of Digital SMEs Kampongs to the aspects of smart city development.

In Indonesia the existence of small and medium enterprises have a big role in supporting the economy of the community. Small and middle enterprises are seen to play an essential role in the economic growth and industry of a country 
(Husband and Purnendu, 1999; Mahemba and De Bruijn, 2003; Tambunan, 2005). An arising problem SMEs faces is how to market their products. It costs a lot to use the conventional way of promotion. Therefore, the presence of internet is expected to be an efficient means of opening the marketing lane for products with relatively low cost, fast response, and much more extensive coverage, popularly called e-commerce (Supardi and Dores, 2009). Utilization of e-commerce as a media campaign or search for business opportunities in SMEs must be balanced with proper administrative management through the use of appropriate software such as for website development (Jauhari, 2010). The use of e-commerce as a medium for promoting products or searching business opportunities for SMEs needs to be balanced with well-managed administration through the use of appropriate software by, for example, designing website (Jauhari, 2010). It is necessary for the SMEs agents to use the information technology advances in improving their business.

In general, there are several other benefits of doing an electronic transaction on trade. According to Sholekan (2009), the benefits that a company gets are shortening distances, broadening market coverage, making business partners easily, and saving time. Therefore, the use of e-commerce needs to be taken into consideration as the one related to the impacts that may happen to SMEs, whether this is viewed from the sides of consumers, suppliers, products or services, and methods applied in businesses (Kartiwi and MacGregor, 2007).

The Digital SMEs Kampongs is the utilisation of information technology in a comprehensive and integrated way to support business process operating in the SMEs areas to realise the SMEs that are growing well, self-reliant, and modern. The idea of Digital SMEs Kampongs is a part of the programs from BAGUS Indonesia (Aspiration Building for One Million Movements of SMEs all over Indonesia). It is the realisation of company social responsibility of PT Telekomunikasi Indonesia (PT Telkom) to help the Indonesian SMEs improve their competence in a modern way. By using ICT, it is expected that SMEs can have competitiveness globally and contribute to the Indonesian economic growth (PT Telkom Indonesia, 2016). The implementation of Digital SMEs Kampongs enables the telecommunication infrastructure network to be available to reach the whole areas of SMEs Kampongs, establish a community forum for SMEs, and help solve the information technology services within the SMEs Kampongs. All over Indonesia, there are 180 Digital SMEs Kampongs under the guidance of PT Telkom. They produce various kinds of goods, such as handicrafts, foods, batik, clothes, and crops.

\section{The implementation of digital SMEs Kampongs}

This paper will discuss the implementation of Digital SMEs Kampongs based on four case examples found in the Digital SMEs i.e. Batik Laweyan Digital SMEs Kampong in Surakarta City, Borobudur Mandala Wisata Digital SMEs Kampong in Magelang Regency, Digital SMEs Kampong of Griya in Yogyakarta City, and Omah Salak Digital SMEs Kampong in Sleman Regency. The location of study which consisted of the four Digital SMEs Kampong is shown in Table 1 and Figure 1. 
Table 1. Cases of Digital SMEs Kampongs: Location and Product

\begin{tabular}{llll}
\hline No & Name & Location & Product \\
\hline 1 & $\begin{array}{l}\text { Batik Laweyan Digital SMEs } \\
\text { Kampong }\end{array}$ & Surakarta City & Batik \\
\hline 2 & $\begin{array}{l}\text { Borobudur Mandala Wisata } \\
\text { Digital SMEs Kampong }\end{array}$ & Magelang Regency & Homestay \\
\hline 3 & $\begin{array}{l}\text { Omah Salak Digital SMEs } \\
\text { Kampong }\end{array}$ & Sleman Regency & Fruit-Agriculture \\
\hline 4 & Griya Digital SMEs Kampong & Yogyakarta City & $\begin{array}{l}\text { Centre for Handicraft } \\
\text { (Showroom) }\end{array}$ \\
\hline
\end{tabular}

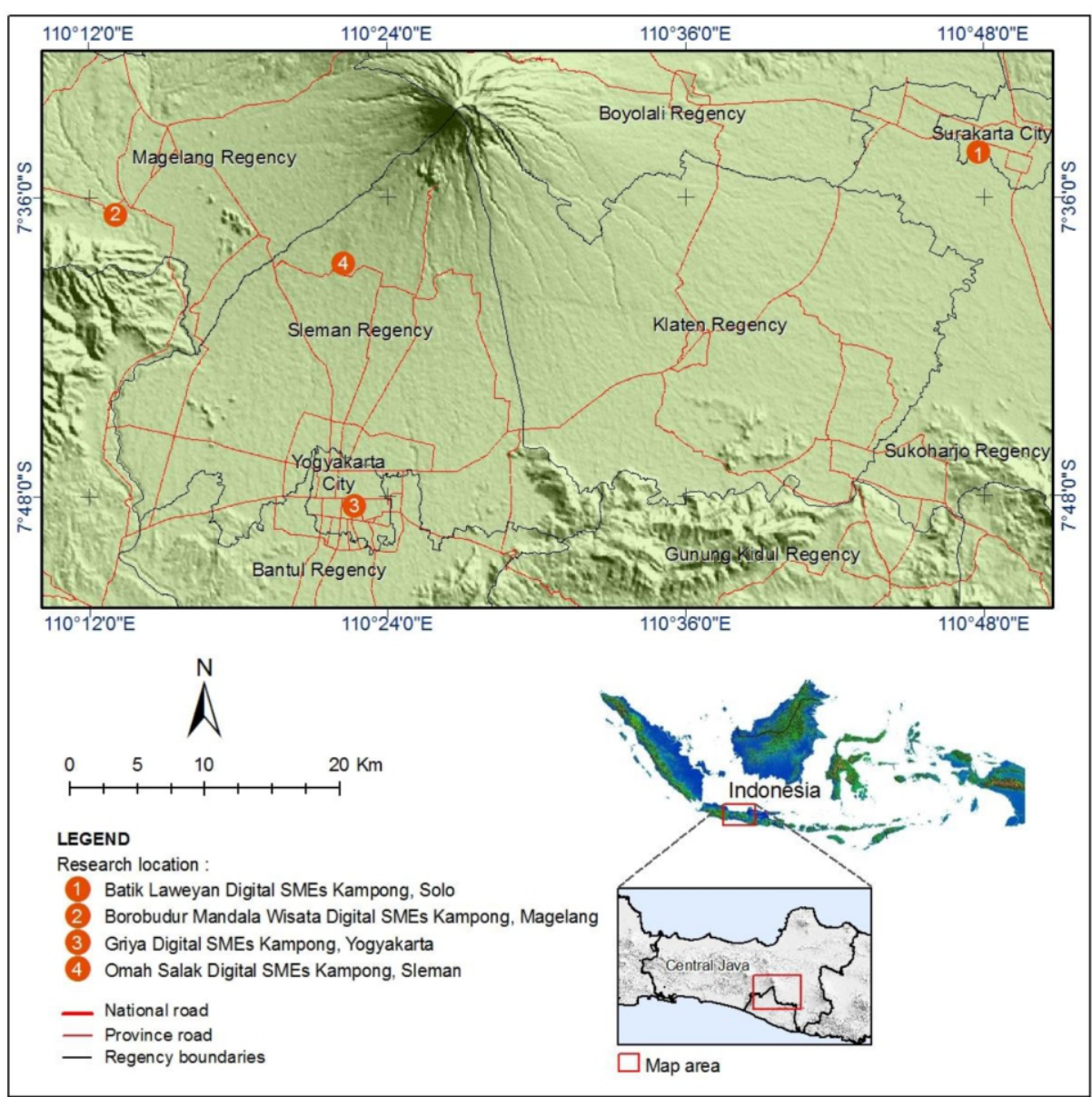

Figure 1. The Study Area

\section{Batik Laweyan digital SMEs Kampong, Surakarta City}

Laweyan is Indonesia's oldest batik kampong that has been in existence since the 15th century. Since 2004 Laweyan has come up with new branding as a Batik Kampong that puts several aspects into priority. They are batik, education, heritage, history tourism, and IT-based industrial and environmentally-friendly area. 
The Batik Kampong of Laweyan consists of 72 business units (Figure 2) classified into large, middle, and small scales. Batik business there has been in existence descending from one generation to the next ones. The improvement of SMEs is merely focused on the typical characteristics and the utilisation of internet for the promotion and order systems. The promotion covers the areas of the home country and overseas, like European countries, Singapore, the United States of America, and China. PT Telkom appointed the Batik Kampong of Laweyan to be the Digital SMEs Kampong in 2015 and launched it the following year. Some activities initiated by PT Telkom to Batik Laweyan Digital SMEs Kampong is to provide training on Online Shop, Jarvis Store, and Online Store Templates that have been prepared to facilitate the business run. In addition, PT Telkom provides computers, internet access, and BLC (Broadband Learning Center).

The government also gives support to the Batik Laweyan Digital SMEs Kampong through the Agency for Cooperative and Small and Middle Micro Enterprises and the Agency for Tourism. Besides, the government also gives the training to improve the Quality of Human Resource.

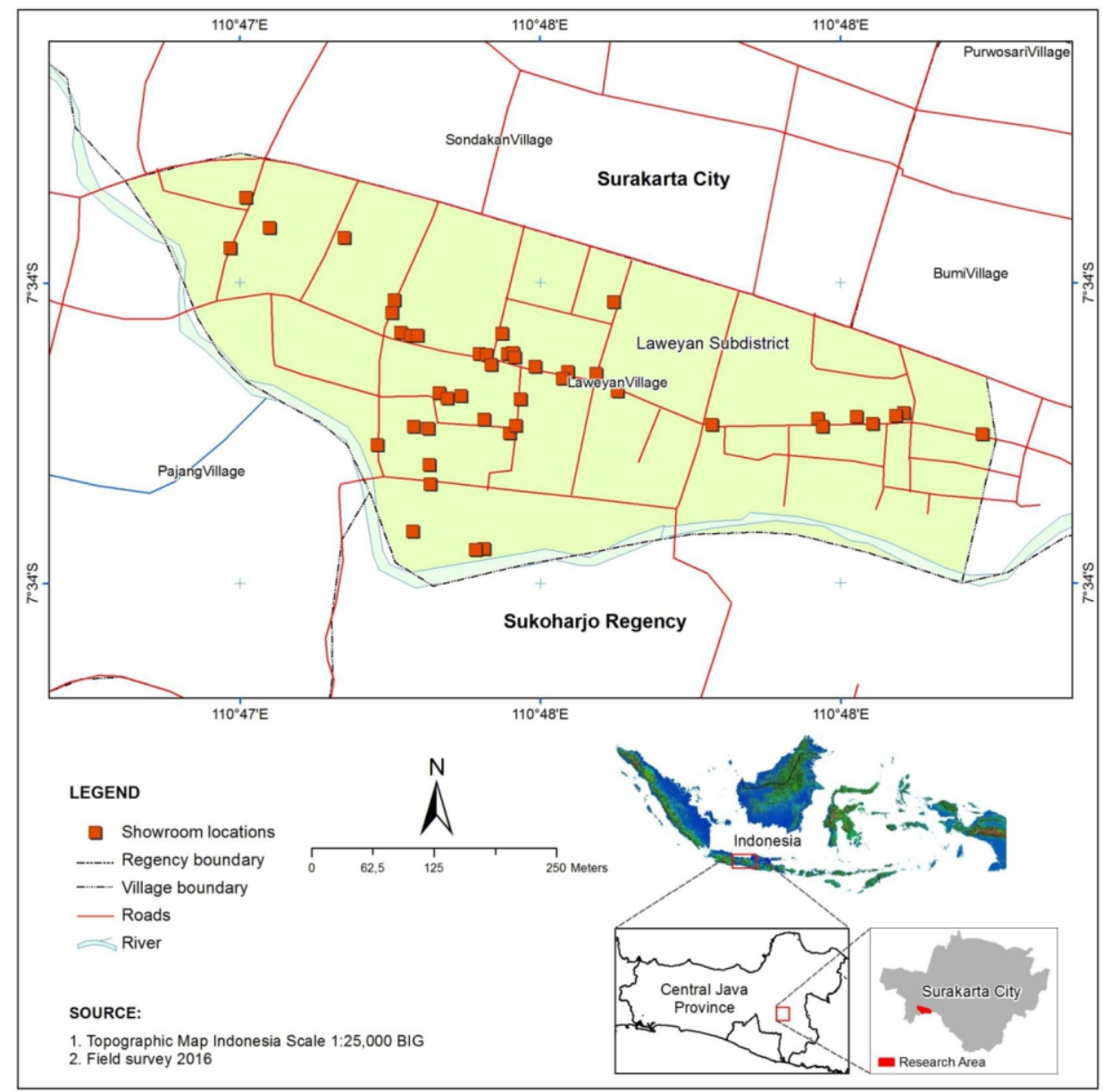

Figure 2. Showroom Distribution of Batik Business Units in Kampong Laweyan, Surakarta City 
The Forum for the Improvement of Batik Kampong of Laweyan is in charge of promotion and publication for each business unit by designing a website. It is used to spread out information globally. IT activators are actively operating the website. However, there are several SMEs of Batik Kampong of Laweyan that have equipped themselves with their webs to promote their products. Besides, there are also several others that improve their online system. Each unit of SMEs has its different system for buying and making an order. The ICT media used are a website, handphone, social media (Facebook). For payment, ebanking has already been used.

The influence of ICT utilization to the improvement of the SMEs of Laweyan Batik is so significant that many people have been familiar with the batik kampong of Laweyan. Therefore, it is easy now to access the existence of batik kampong of Laweyan due to the presence of ICT there. Besides, the presence of ICT is also able to attract more consumers to come and that the income also increases. The use of ICT also enables the units to improve their businesses so that they can follow the trend by creating innovations. Figure 3 shows the use of ICT in Batik Laweyan Digital SME Kampung, Surakarta City.

The plan to improve the Digital SMEs Kampong is by creating program innovation and a new application to answer the global challenge. The Forum for the Improvement of Laweyan Batik will also identify business units that are not enlisted to participate in the program so that it is much easier to manage the Digital SMEs Kampong. The participation of the people and business people there to support the Digital SMEs Kampong is very high because the benefits they get can increase their economy and give ease.
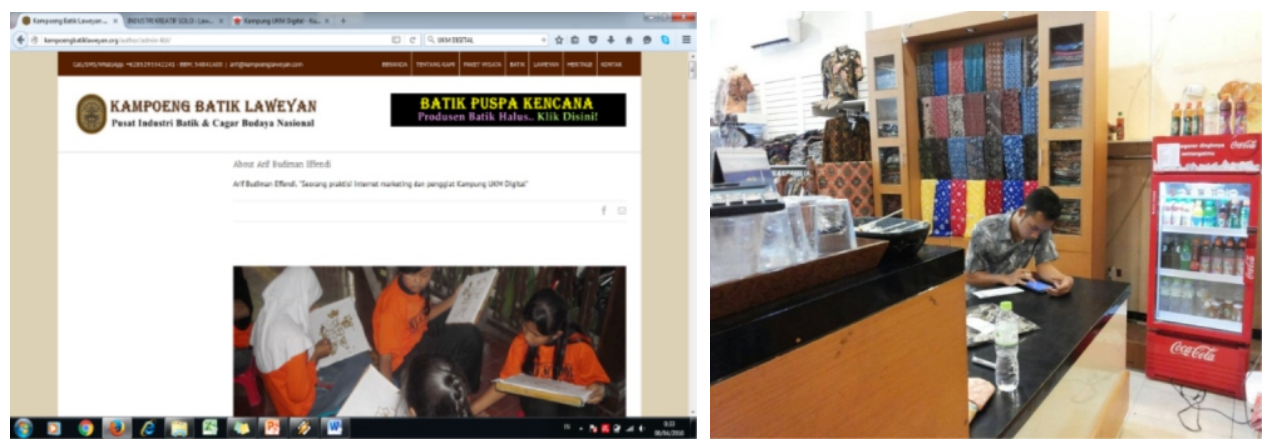

a. Website for Online Marketing

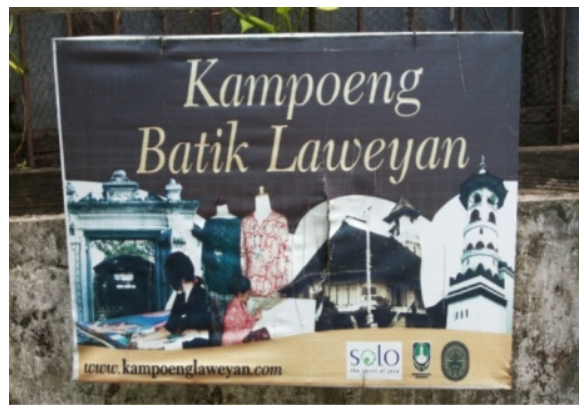

c. Laweyan Batik Kampoeng Notices

b. Selling the Product Online and Website Address

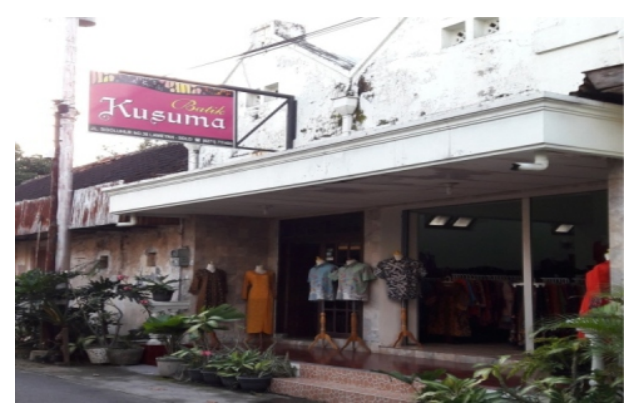

d. One of the SMEs Showrooms

Figure 3. The Use of ICT in Batik Laweyan Digital SMEs Kampong, Surakarta City 
However, there are also some obstructions faced to implement the Batik Laweyan Digital SMEs Kampong. They are, among others, limited space for training, different people's response due to their understanding of the concept of Digital SMEs Kampong, and a limited number of gadgets.

\section{Borobudur Mandala Wisata digital SMEs Kampong, Magelang Regency}

The Digital SMEs Kampong of Borobudur Mandala Wisata is located in the village of Wanurejo, Borobudur, 600 meters from the Borobudur Temple. It becomes the entrance of the temple. The concept of this kampong tourism is "touring back home to the village." Homestays with different facilities are available. So far the use of ICT has only been limited to promotion. An example of it is by making use of social media like Facebook. Several tourists asked for the photos of this tourism village using the social media Facebook.

PT Telkom gives help in publication and training. The central office of PT Telkom did the monitoring and declared Mandala Wisata officially as the Digital SMEs Kampong. The Regional Government of the Regency of Magelang also participated in the inauguration of the Borobudur Mandala Wisata Digital SMEs Kampong. It issues some regulations on a homestay. The application of ICT is given to only one central SMEs. PT Telkom also once provided training to the people there. It is not given routinely, however. In addition, not all cooperative members have been using ICT. The situation of homestay at Borobudur Mandala Wisata Digital SMEs Kampong at Magelang Regency can be seen in Figure 4.

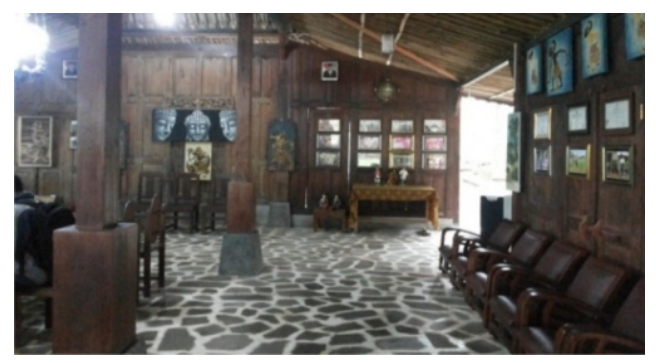

a. Homestay Living Room

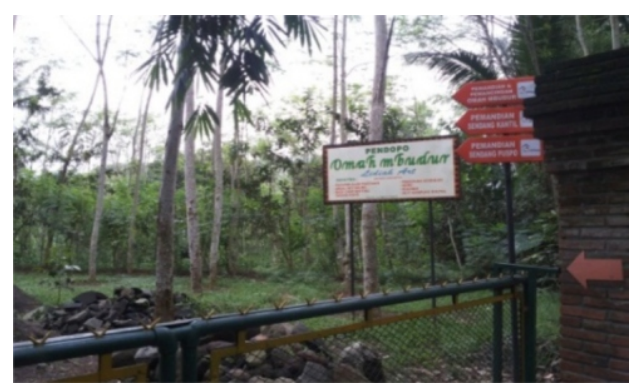

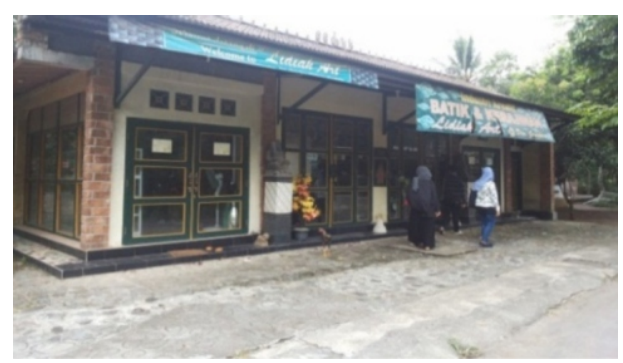

b. Craft Showroom

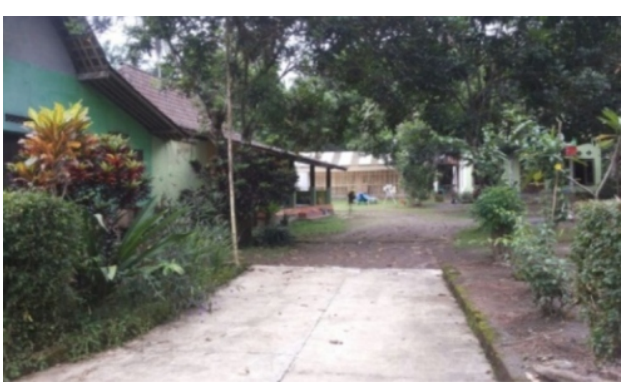

c. Natural Rural Homestay Environment

Figure 4. Homestay and Surrounding Area at Borobudur Mandala Wisata Digital SMEs Kampong, Magelang Regency 
The participation of the people there to support the implementation of Borobudur Mandala Wisata Digital SMEs Kampong is good enough. However, the problem is that there are still many people there who do not have the gadgets to support the Digital SMEs Kampong. Consequently, those who have even attended the training still cannot apply the ICT directly. Nevertheless, there has been a significant improvement after the installation of information technology network. In 2013, there were between 2,000 and 3,000 visitors. The presence of internet has kept attracting more people to visit. By the end of 2015, there had been 6,700 visitors to this tourism kampong.

\section{Griya digital SMEs Kampong, Yogyakarta City}

The Digital SMEs Kampong of Griya (Figure 5) is located in the city of Yogyakarta. It functions as a place for giving training and assistance. However, the primary function of it is as a showroom for displaying various kinds of craft supplied by Micro, Small, Medium Enterprises (MSMEs) here are 325 MSMEs in the city of Yogyakarta joining this Digital SMEs Kampong of Griya. The Digital SMEs Kampong of Griya is aimed at assisting so that the business agents there can improve their own business with the help of the utilization of ICT. The establishment of this kampong is under the guidance of the Agency for Industry, Trade, and Cooperative, mainly on the field of the Resource Development of Small and Middle Micro Enterprises.

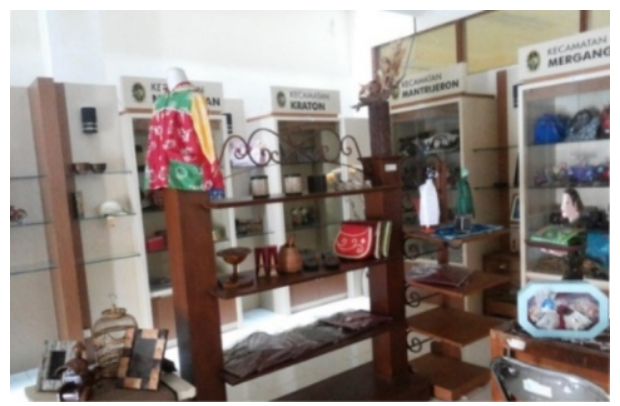

a. Display of Handicrafts from all districts in Yogyakarta City

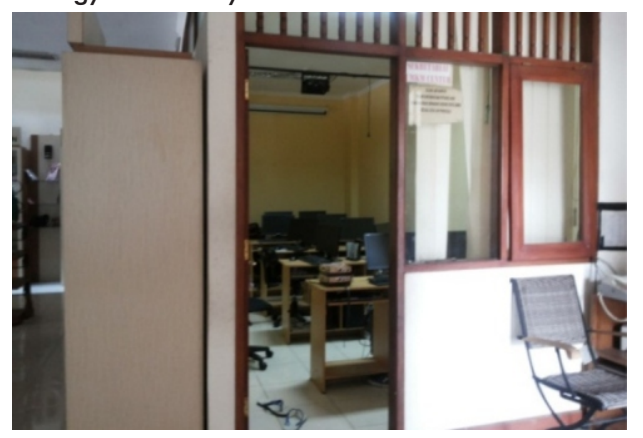

c. IT Room For Training Uses Technology For SMEs

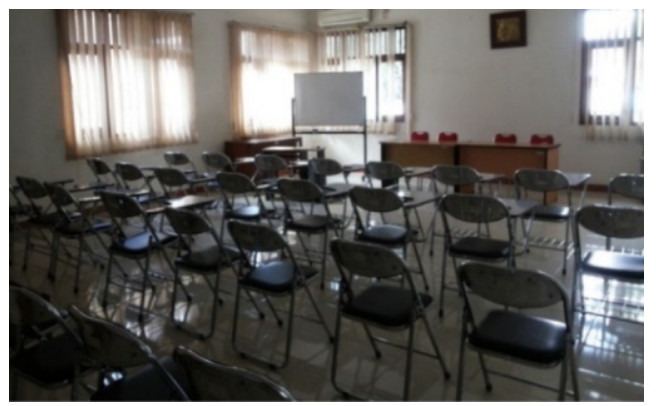

b. Meeting Room for SMEs Member

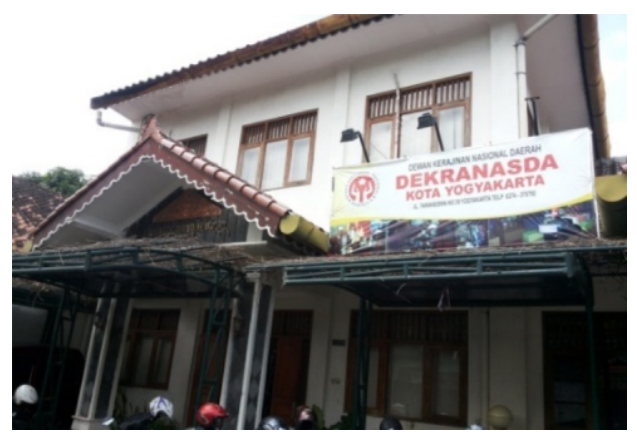

d. Office of Griya Digital SMEs Kampong

Figure 5. Centre for Handicraft (Showroom)-Griya Digital SMEs Kampong, Yogyakarta City 
The Digital SMEs Kampong of Griya was established in 2015. The establishment from Kampong Griya to the Digital SMEs Kampong was initiated by the regional government with the help of PT Telkom as part of its Corporate Social Responsibility (CSR). The Digital SMEs Kampong of Griya facilitates the availability of internet for MSMEs and also functions as a facilitator for MSMEs to promote, develop, and give assistance. One of the elements found in this kampong is the availability of service unit for business consulting to the MSMEs agents when they find difficulties promoting their products and running their business. This consulting service is provided by utilizing information technology available on social media, such as WhatsApp and BlackBerry Messenger.

PT Telkom provides computer sets, LCD, and screen. Besides, it also assists the business agents thereby giving them training on how to design product website and how to market products digitally. Support from the regional government to this Digital SMEs Kampong is by providing internet, electricity, and building. Besides, the government also takes part in promoting this Digital SMEs Kampong of Griya.

The utilization of ICT as a whole is a website, handphone, and e-banking. Each MSMEs makes use of it differently by its own need and products. Thus, the management of Kampong Griya is only to assist the business agents. The use of ICT also contributes to innovation in promotion for several MSMEs, like applying e-commerce and online shop. The utilization of ICT helps MSMEs agents get information, and this is very useful for them to update products favored by consumers. Therefore, they are also able to make innovation for their products. There are several plans made, i.e., promoting online-based products of MSMEs and optimizing the benefits of information from the website. On that website appears the mapping of MSMEs into which the contents are classified, i.e., names, descriptions of MSMEs, and pictures of business products. Nevertheless, there are also obstacles that the MSMEs agents face. They are, among others, their low knowledge of computer system that uses English, their spending more time on production process than on digital promotion. However, because of their high motivation to use ICT, most MSMEs agents are already prepared to use technology in improving their businesses.

\section{Omah Salak digital SMEs Kampong, Sleman Regency}

The SMEs Kampong of Omah Salak is located in the village of Donokerto, subdistrict of Turi, the regency of Sleman. The Kampong of Omah Salak is designed to be the information center for groups of farmers and has developed to be one of the places for study tourism. Omah Salak is incorporated with 40 groups of farmers, each of whom consists of between 40-20 farmers. Thus, Omah Salak is incorporated with at least 1,600 farmers. There are various activities (Figure 6) in the Kampong of Omah Salak, from processing the agricultural crops to serving visitors in this tourism village. The Kampong of Omah Salak helps to promote fresh fruit, provides consultants for salak (snake fruit) farming in other areas, and gives assistance to developing tourism villages. This tourism village offers several tour packages, such as study tour, out-bound, homestay, etc. 
The Digital SMEs Kampong of Omah Salak along with 100 other tourism villages was launched in 2015, taking place in Denggung, Regency of Sleman. Omah Salak plays an important role in processing and improving agricultural crops and promoting them. Since its establishment, Omah Salak has been incorporating with farmers so that it can give help and promote the use of technology. Therefore, farmers that used to cultivate the land traditionally can be taught in a modern way from the sides of management and promotion. It is an excellent role for the farmers in promoting their crops by using new access, like internet. Besides, Omah Salak also plays a vital role in involving farmers to be technologically literate so that they can improve their ability in the product promotion in more quality. Up until now, Omah Salak has been enlisted to be the Digital SMEs Kampong independently. The groups of farmers in the kampong of Omah Salak have a forum called Forum Dewi Omah Salak.

The utilization of ICT in Kampong Omah Salak is limited to website, Facebook, and Instagram. It is they that provide internet since there has been no help from both private companies and government related to ICT facility. The use of ICT has led to the increasing number of visitors since they can do the browsing on the internet. ICT has been used by groups of farmers to share information. The management of Omah Salak keeps updating and that the young people there can help farmers share information. ICT is utilized since it is more efficient and cheaper, and it covers large areas. Before ICT was first used, promotion was done by displaying products in exhibitions. Today, from the Kampong of Omah Salak, products can be promoted in a much faster and larger way just by using the internet.

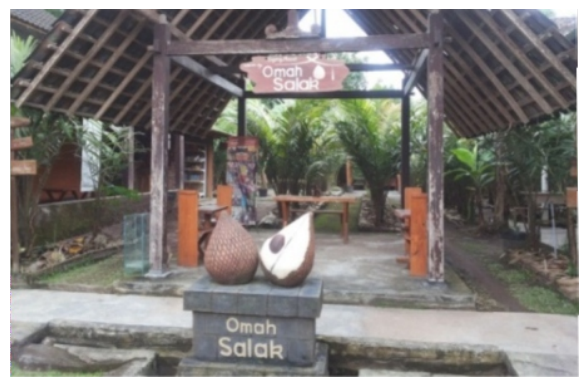

a. Omah Salak as a Center of Tourism Information and Fruit Processing

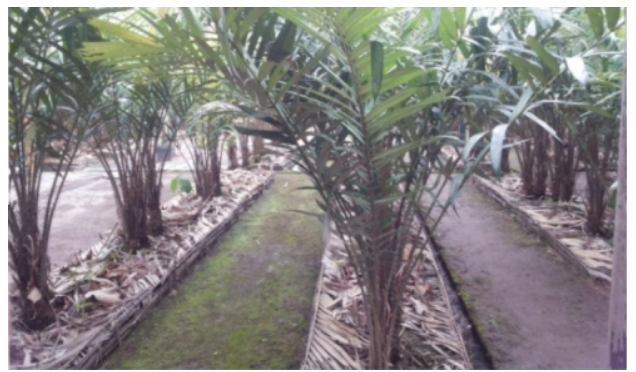

c. Salak Plantation

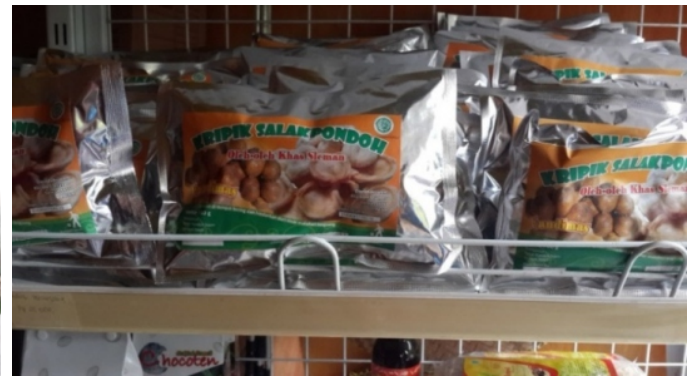

b. Examples Processed Products

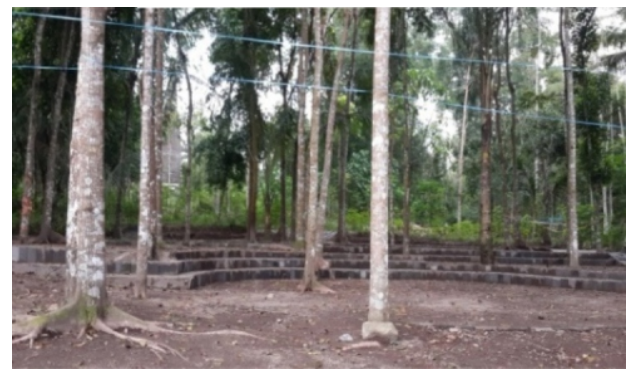

d. Tourist Attractions and Outbound Activities

Figure 6. Fruit Agriculture Activities-Omah Salak Digital SMEs Kampong, Sleman Regency 


\section{Implications of the utilization of virtual space in the digital SMEs Kampong on the aspects of the development of Smart City and Region}

Cities in several countries have been in transition from representing typologies as a new city. One of them is a smart city that represents the city development related to city services based on the utilization of ICT (Nallari et al., 2012; Albino et al., 2015; Rachmawati, 2014).

There are many definitions of Smart City. One of them is that a city will become smart when investment on human resources, infrastructure, and communication system can boost economic growth sustainably and improve the quality of people's lives (Caragliu et al., 2011). The characteristics of a smart city, according to Giffinger et al. ( 2007), are, among others, 1) Smart Economy, comprising factors like innovation, entrepreneurship,self-branding, productivity, and competitiveness in the global market, 2) Smart People, not only related to the level of their education but also how social interaction takes place in the society, 3) Smart Governance, comprising factors of, for example, political participation, service quality, and public administration, 4) Smart Mobility, supported by local and international accessibility with the help of ICT availability and transportation system that is environmentally friendly, 5) Smart Environment, related to the issues of preservation for natural environment, and 6) Smart Living, related to aspects of the city people's quality of life.

There is no need to develop those elements altogether. However, the development of a city can be focused on one or some aspects only, depending on the potentials and characteristics of the city (Giffinger et al., 2007). Chourabi et al. (2012) show that one of the components of a smart city is a smart economy, which cannot be separated from external factors, like government, society, natural environment, and supporting infrastructure. It is so because a city is signed with high economical competitiveness so that smart economy plays an essential role in developing a smart city and that it plays a more important role than other components of a smart city (Chourabi et al., 2012). Meanwhile, Bakici et al. (2013) reveal that smart economy involves the establishment of clusters in making innovations and cooperation among enterprises, research institutions, and the society in the context of developing, implementing and promoting innovations through the network available. Zygiaris (2013) confirms that smart economy is an ability to make use of the existing resources to develop and implement an innovative solution.

From the study of cases, the implementation of Digital SMEs Kampongs shows that the utilization of virtual space for the sake of improving small and middle enterprises is highly needed. It will give positive impacts to the development of people's economy and regional economy. It will be made possible due to the ease of promotion, publication, and order by utilizing virtual space with the help of ICT. The implementation of Digital SMEs Kampong is, in fact, able to give impacts to the development of a region and to support the development acceleration of business process in a systematic way. By making use of ICT, small and middle enterprises are expected to be able to make progress and not to be left behind in the global competition and that the society will live more prosperous. In the context of developing a smart city and smart region, by utilizing the virtual space in the case of implementing Digital SMEs Kampong, it shows that 
there has been strengthening in making people smart by making use of ICT by, primarily, business agents. The same case is a smart business that is formed by operating and improving business supported by ICT. Smart economy is created through the concept and system of developing business integrated among various business activities and agents. The same case is the plan to establish an ICT-based business in the future. With the availability of the components like smart people, smart business, and the smart economy as well as the support from the smart government through its services, it is easy to achieve the orientation of establishing a smart city and smart region.

\section{Conclusion}

Virtual space utilization in the activities of SMEs provides benefits in improving access in promoting the products and market expansion as well as easy ways to trade through e-commerce. The existence of the Digital SMEs Kampong program is not only beneficial to their development but also the region. Digital SME Kampongs development, as part of the implementation of the smart city and region through the strengthening of the smart economy, is supported by smart people and smart government.

\section{Acknowledgements}

The author wishes to thank the Faculty of Geography, Universitas Gadjah Mada for the Research Grant in the year 2016.

\section{References}

Albino, V., Umberto, B. and Rosa, M.D. (2015), "Smart Cities: Definitions, Dimensions, Performance, and Initiatives", Journal of Urban Technology, vol. 22, no. 1, p. 3-21.

Bakici, T., Almirall, E., and Wareham, J. (2013), "A Smart City Initiative: The Case of Barcelona", Journal of the Knowledge Economy, vol. 4, no. 2, p. 135-148.

Bifulco, F., Tregue, M., Amitrano, C.C., and D'Auria, A. (2016), "ICT and Sustainability in Smart Cities Management", International Journal of Public Sector Management, vol. 29, no. 2, p. 132-147.

Caragliu, C. Del Bo, and Nijkamp, P. (2011), "Smart cities in Europe", Journal of Urban Technology, vol.18, no. 2, p. 65-82.

Chourabi, H., Nam, T., Walker, S., Gil-Garcia, J.R., Mellouli, S., Nahon, K., Pardo, A.T. and Scholl, H.J. (2012), "Understanding Smart Cities: An Integrative Framework", 45th Hawaii International Conference on System Sciences, p. 2289-2297.

Giffinger, R., Fertner, C., Kramar, H., Kalasek, R., Pichler-Milanovic, N. and Meijers, E. (2007), "Smart Cities-Ranking of European Medium Sized Cities", Vienna University of Technology.

Goodall, B. (1987), Dictionary of Human Geography, London: Penguin Group. 
Husban, S. and Purnendu, M. (1999), "A Conceptual Model for Quality Integrated Management in Small and Medium Size Enterprise", International Journal of Quality E Reliability Management, vol. 16, no. 7, p. 699-713.

Jauhari, J. (2010), "Upaya Pengembangan Usaha Kecil dan Menengah (UKM) dengan Memanfaatkan E-Commerce", Jurnal Sistem Informasi, vol. 2, no. 1, p. 159-168.

Kartiwi, M. and MacGregor, R.C. (2007), "Electronic Commerce Adoption Barriers in Small to Medium-Sized Enterprises (SMEs) in Developed and Developing Countries: A Cross-Country Comparison", Journal of Electronic Commerce in Organizations, vol. 5, no. 3, p. 35-51.

PT Telkom Indonesia, (2016), Kampung UKM Digital, 21 March 2016, (https://goo.gl/qWMhZy)

Mahemba, C.M. and De Bruijn, E.J. (2003), "Innovation Management Practices of Small and Medium Scale Enterprises in Tanzania", Creativity and Innovation Management, vol. 12, no. 3, p. 162-173, Oxford and London: Blackwell Publishing Ltd.

Nallari, R., Griffith, B. and Yusuf, S. (2012), Geography of Growth: Spatial Economics and Competitiveness, World Bank Publications, The World Bank, no. 6020 .

Rachmawati, R. (2011), "Perubahan Pola Spasial Pergerakan Penduduk dan Lokasi Pelayanan Ekoomi yang Tersubsitusi oleh Teknologi Informasi dan Komunikasi (Studi Kasus: Perkotaan Yogyakarta)", Disertasi, Universitas Gadjah Mada.

Rachmawati, R. and Rijanta, R. (2012), "Population Mobility and Urban Spatial Structure: Does the Use of Information and Communication Technology Matter?", Regional View, Japan, no. 25, p. 9-19.

Rachmawati, R. (2014), Pengembangan Perkotaan dalam Era Teknologi Informasi dan Komunikasi, Yogyakarta, UGM Press.

Rachmawati, R., Rijanta, R. and Djunaedy, A. (2015), "Location Decentralization Due to The Use of Information and Communication Technology: Empirical Evidence from Yogyakarta, Indonesia", Human Geographies - Journal of Studies and Research in Human Geography, vol. 9. no. 1.

Rachmawati, R. (2016), "Urbanization in The Era of Information and Communication Technology (ICT)", Proceeding Asian Urbanisation Conference, Yogyakarta, Indonesia, Badan Penerbit Fakultas Geografi, Universitas Gadjah Mada.

Sholekan, (2009), E-commerce, Bandung, Telkom PDC.

Supardi, J. and Dores, V. (2009), "Rancang bangun Collaborative System Pemasaran Hotel secara On-line dengan Pendekatan Mediator Based", Jurnal Sistem Informasi, vol. 1, no. 2, p.55-61.

Tambunan, T. (2005), "Promoting Small and Medium Enterprises With a Clustering Approach: A Policy Experience from Indonesia", Journal of Small Business Management, vol. 43, no. 2, p. 138-154.

Zygiaris, S. (2013), "Smart City Reference Model: Assisting Planners to Conceptualize the Building of Smart City Innovation Ecosystems", Journal of the Knowledge Economy, vol. 4, p. 217-231. 